\title{
SIM1 wt Allele
}

National Cancer Institute

\section{Source}

National Cancer Institute. SIM1 wt Allele. NCI Thesaurus. Code C75506.

Human SIM1 wild-type allele is located within $6 q 16.3-q 21$ and is approximately $80 \mathrm{~kb}$ in length. This allele, which encodes single-minded homolog 1 protein, plays roles in regulation of transcription, neurogenesis, and may also play a role in regulation of feeding behavior. Mutations in this gene are associated with a Prader-Willi-like phenotype. 